ppi $201502 Z U 4645$

Esta publicación científica en formato digital es continuidad de la revista impresa ISSN-Versión Impresa 0798-1406 / ISSN-Versión on line 2542-3185Depósito legal pp $197402 Z$ U34
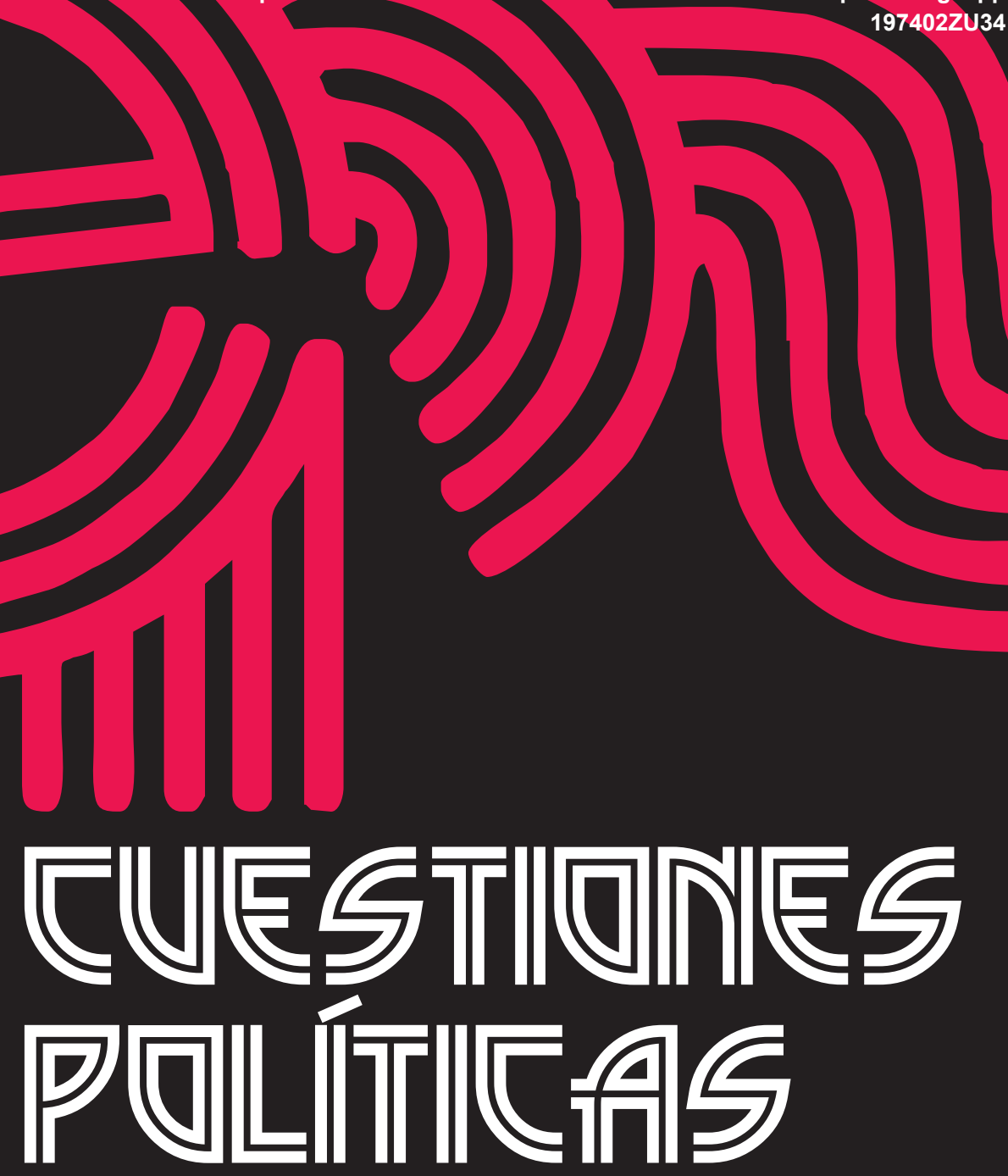

Instituto de Estudios Políticos y Derecho Público "Dr. Humberto J. La Roche" de la Facultad de Ciencias Jurídicas y Políticas de la Universidad del Zulia Maracaibo, Venezuela
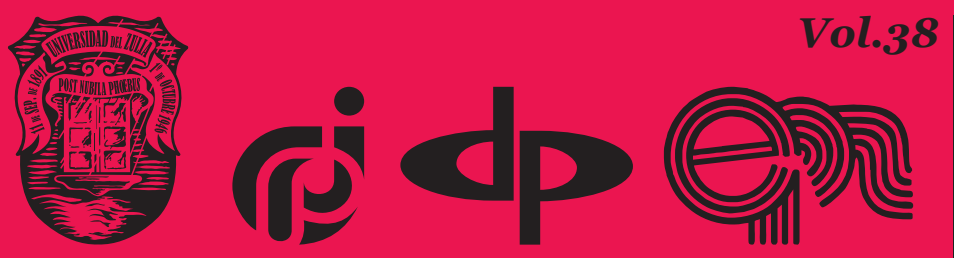

$N^{\circ}$ Especial 2da Parte 2020 


\title{
Tendencies for the Development of Marriage Conflict Legal Regulation with the Participation of Foreigners and Persons without Citizenship in the Post-Soviet Space
}

\author{
DOI: https://doi.org/10.46398/cuestpol.382e.27
}

\author{
Gulshan Gurezovna Bodurova * \\ Sanavbar Nazirkulovna Tagaeva **
}

\begin{abstract}
The article describes trends in the development of legal regulation linked to collisions that regulate marriage matters under the laws of post-Soviet countries. At the methodological level it is a comparative research of documentary basis. It is noted that, despite the general historical development of legal institutions and ongoing harmonization, the regulation of the principles of marriage collision has its own peculiarities in the countries of the former Soviet Union. This trend is explained by the specific and heterogeneous regulation of marriage and family relations in the legislation of different countries. But in the context of integration processes, the displacement of people from one country to another, marriage and family relationships also tend to develop. The article provides comparative analysis of the vast material, especially regulatory legal acts of post-Soviet countries, which regulate marriage and family relations in order to identify common and special characteristics. They revealed trends in the regulation of marriage conflicts in post-Soviet countries, as well as the regulation of marriage disputes in a consular office or diplomatic mission.
\end{abstract}

Keywords: forms of marriage; material conditions of marriage; conflict regulation; post-Soviet space; legal trends.

\footnotetext{
* Candidat of Law,Faculty of Law, Department of International and European Law ,Kazan Federal University, Kazan, Russia (Russian Federation). ORCID ID: https://orcid.org/oooo-0oo2-62938809. Email : bodurova.gulshan@gmail.com

** Doctor of Law, Associate Professor, Department of Civil Law, University of Management «TISBI», Kazan, Russia (Russian Federation). ORCID ID: https://orcid.org/oooo-ooo2-8831-9344. Email: s.tagaeva@mail.ru
} 
Gulshan Gurezovna Bodurova y Sanavbar Nazirkulovna Tagaeva

Tendencies for the Development of Marriage Conflict Legal Regulation with the Participation of

Foreigners and Persons without Citizenship in the Post-Soviet Space

\section{Tendencias para el desarrollo de la regulación legal de los conflictos matrimoniales con la participación de extranjeros y personas sin ciudadanía en el espacio postsoviético}

\section{Resumen}

El artículo describe las tendencias de desarrollo de la regulación legal vinculada a colisiones que regulan los asuntos matrimoniales bajo las leyes de los países postsoviéticos. A nivel metodológico se trata de una investigación comparada de base documental. Se observa que, a pesar del desarrollo histórico general de las instituciones legales y la armonización en curso, la regulación de los principios de colisión del matrimonio tiene sus propias particularidades en los países de la ex Unión Soviética. Esta tendencia se explica por la regulación específica y heterogénea del matrimonio y las relaciones familiares en la legislación de diferentes países. Pero, sin embargo, en el contexto de los procesos de integración, el desplazamiento de personas de un país a otro, el matrimonio y las relaciones familiares también tienden a desarrollarse. El artículo proporciona el análisis comparativo del vasto material, especialmente los actos legales regulatorios de los países postsoviéticos, que regulan el matrimonio y las relaciones familiares con el fin de identificar características comunes y especiales. Revelaron las tendencias de la regulación de los conflictos matrimoniales en los países postsoviéticos, así como la regulación de los conflictos matrimoniales en una oficina consular o misión diplomática.

Palabras clave: formas de matrimonio; condiciones materiales del matrimonio; regulación de conflictos; espacio postsoviético; tendencias legales.

\section{Introduction}

The uniqueness of the historical path, the specificity of religious and cultural landmarks, and traditions is reflected in the legal regulation of family relations. Marriage relations as a part of family relations are strongly influenced by society, therefore, are taken into account by state institutions during legal regulation mechanism establishment. State interests, combined with the delicacy of marriage relations, are reflected in the legal regulation of relations with the participation of foreigners and stateless persons. The significance of such regulation is dictated by the following postulate: "marriage is an inevitable part of existence, the choice not to marry almost does not exist" (Sen et al., 2011: 215). 
The legal regulation of marriage relations with the participation of foreigners and stateless persons has its own specifics in the countries of the former Soviet Union, despite the existing harmonization processes.

So, there are two trends in the issues of marriage conflict regulation within the post-Soviet space:

a) providing the opportunity for conflict regulation of marriage relations by the persons entering marriage via legal consequence determination.

b) increased state intervention in the marriage conflict regulation.

When a marriage is concluded with the participation of foreigners or stateless persons, conflicts arise related to the form and order and material conditions of marriage.

A marriage must be performed in a certain form, so that it will have legal consequences. So, the most common conflict binding that has effect in all legal systems is lex loci celebrationis - the law of the place of marriage. This collision principle has been enshrined in the laws of the post-Soviet states.

\section{Methods}

The article uses both general scientific methods of scientific knowledge and private scientific methods. Among them are the following ones: analysis, synthesis, comparison, formal legal and technical legal.

\section{Results and Discussion}

Thus, the form and procedure of marriage on the territory of the Russian Federation are determined by the Russian Federation legislation (the Article 156 of the RF FC).

As for the marriage conflict regulation in the post-Soviet countries, two legislation development trends can be seen: a) in favor of recognizing the territorial principle as the main conflict of reference in marriage material term regulation; $b$ ) in favor of the personal law of a foreigner (in this case, lex patriae) as determining one in the matters of marriage material conditions.

Based on the general historical development of family relation legal regulation, many post-Soviet countries joined the Minsk and Chisinau Conventions of the CIS "On Legal Assistance and Legal Relations in Civil, Family and Criminal Matters" issued in 1993 and 2001. These international 
Gulshan Gurezovna Bodurova y Sanavbar Nazirkulovna Tagaeva

Tendencies for the Development of Marriage Conflict Legal Regulation with the Participation of 354

Foreigners and Persons without Citizenship in the Post-Soviet Space

treaties contain conflicting principles that are used to regulate the issues of marriage between the citizens of participating countries.

In accordance with the Art. 26 of Minsk Convention and the Art. 29 of the Chisinau Convention, the conditions for marriage are determined for each of the future spouses by the legislation of the country of which he/she is a citizen, and as for stateless persons - by the legislation of the country that is their permanent place of residence. Besides, with regard to marriage obstacles, the legislation of the state must be observed on the territory of which the marriage is concluded.

The territorial approach that existed earlier during the Soviet period to regulate the material conditions of marriage was criticized by Panteleeva (1986) and Lundstedt and Sinander (2020) who expressed proposals on mitigating the territorial principle in marriage issues and on the transition to material and legal condition regulation by the personal law of the couple for foreigners who marry in the USSR (Matveev, 1972; Lundstedt and Sinander, 2020; Panteleeva, 1986).

Nowadays, this position has been reflected in the Family Code of the Russian Federation, which subordinated in the article 156 the conditions for marriage in the country to the personal law of a foreigner, more precisely, the law of citizenship (lex patriae), in compliance with the provisions of the article 14 with respect to the circumstances that impede marriage, confirmed the constitutional equality of the genders, and for stateless persons - to the law of residence (lex domicilii). Identical, so-called more simplified variations of the marriage conflict regulation laws are found in the legislation of international private law in a number of foreign countries. Thus, under Swiss law, the foreigners who do not have a residence in this country can enter into a marriage if such a marriage is recognized in their state of residence or their state of citizenship (Dessemontet and Ansay, 2004; Briggs, 1999).

In accordance with the part 3 of the article 156 of the RF FC, the legislation of the Russian Federation is applied to the terms of marriage, that is, the right to choose a foreign law is not provided for a person who has the citizenship of the Russian Federation along with the citizenship of foreign states.

As for foreigners with several foreign citizenships, it would be more correct to subordinate the conditions for marriage to the principle of closest connection. Since no matter what citizenship, a person has chosen, if it is clearly visible that he has a closer relationship with another law, it is more expedient to subordinate the conditions of marriage to this particular rule of law. Moreover, the concept of "closest connection" or "usual place of residence" within the considered aspect is equally defined in the countries of both general and Romano-German law, and therefore its application 
is "universally welcomed" (Clarkson and Hill, 2006). This is one of the prerequisites for a marriage recognition abroad (in the country with which it is most closely associated).

At the same time, "family law does not take into account certain features of the marriage and family law of other countries" (Mengliev, 2001).

In turn, marriage prohibitions provided for by the "personal law" of foreigners are not taken into account when they enter into marriage in Russia. This applies to such restrictions on the ability to marry, which are established by the domestic law of foreigners on racial, religious and similar grounds.

According to Private International Law of 2005, the legislator of Ukraine adheres to the same principles of conflict regulation by subordinating the marriage form and procedure between a citizen of Ukraine and a foreigner or a stateless person or the marriage between foreigners or stateless persons on the territory of the country to the laws of Ukraine (the art. 56).

And the material conditions of marriage, that is, the right to marry a person is determined by the laws of the state of which he/she is a citizen. But at the same time, the compliance with the legislation of Ukraine is required in order to exclude grounds for declaring a marriage invalid in the future (the Article 55).

An example of the territorial regulation of the material conditions of marriage is the legislation of the Republic of Kazakhstan.

Thus, the Code of the Republic of Kazakhstan "On Marriage (Matrimony)" of 2011 regulates the issues of marriage of Kazakh citizens with foreigners or stateless persons, providing the latter with a national treatment (the Article 228). At the same time, when they apply for marriage, a foreigner grants permission to marry a foreigner from the competent authority of the state of which he is a citizen, if such permission is required in accordance with the legislation of a foreign state. If there is no such permission, the registration authority, upon the application receipt, must explain to the person entering into marriage that his/her marriage may be declared invalid in the country of which the person with whom he/she enters into marriage is a citizen.

If, despite such explanations, the applicants insist on state registration of marriage, this marriage is registered. At the same time, marriage registration, which can be recognized in one state but cannot be recognized in another, may give rise to a "lame relationship". The issue of a marriage, in case of warning the parties about the possible non-recognition of the legal consequences in another state, is made dependent on the will of the persons entering into marriage. This indicates an increasing dispositiveness of marriage conflict regulation. 
Gulshan Gurezovna Bodurova y Sanavbar Nazirkulovna Tagaeva

Tendencies for the Development of Marriage Conflict Legal Regulation with the Participation of 356

Foreigners and Persons without Citizenship in the Post-Soviet Space

The Code of the Republic of Belarus "On Marriage and the Family" also adheres to the territorial principle in the matters of marriage form and procedure, providing for the possibility of marriage between the citizens of the Republic of Belarus and foreign citizens and stateless persons, as well as between foreign citizens or stateless persons by the authorities registering the acts of civil status according to the requirements of the Republic of Belarus legislation (the Articles 229 -229/1). At the same time, the permanent residence of at least one of the persons entering into marriage in the Republic of Belarus is indicated as a requirement for providing foreigners with a national regime in the matters of marriage. In turn, Belarusian legislation temporarily deprives people of the marriage possibility in Belarus via registration authorities.

Different conflict regulation of marriage with the participation of foreigners and stateless persons is observed in the family legislation of the Republic of Tajikistan. The territorial principle of conflict regulation is established in relation to formal conditions and the procedure for marriage (the Article 167 of the RT FC).

The material conditions of marriage are determined by the family legislation of the Republic of Tajikistan for each person entering into marriage, according to the laws of the state of which the person is a citizen at the time of marriage, in compliance with the provisions of the Family Code of the Republic of Tajikistan, which regulates the conditions of marriage for foreigners and the absence of circumstances preventing marriage.

The inclusion of short stories in the Family Code of Tajikistan, in the form of special material conditions of marriage for foreigners, is controversial. The need for legislative consolidation of two more conditions for the citizens of a foreign state - the residence in Tajikistan for at least 1 year and the mandatory conclusion of a marriage contract is certainly caused by the best intentions. But this measure is unlikely to solve the problem of infringement of woman rights who marry a foreign citizen. Besides, a foreigner who wishes to marry our citizen can conclude it in a neighboring state and there will be no reason to invalidate such a marriage.

By virtue of the application of a classic conflict of ties in marriage, complicated by the participation of foreigners, a marriage is valid in those cases when it is valid under the laws of the state in which it is entered into, it will be recognized in Tajikistan. Another point of attention is the strength of this condition when marrying a foreigner - a citizen of the Commonwealth of Independent States, in the framework of which international treaties on legal assistance and legal relations are in force. It turns out that the provisions of Tajikistan family law that are contrary to international agreements will not be taken into account due to the priority of international norms. All these circumstances indicate the incompleteness of these provisions (Sha, 2020). 
You should also pay attention to the content of a marriage contract, which may include provisions that are disadvantageous for a married Tajik woman. For example, a prenuptial agreement may contain the provisions on the joint ownership of spouses, in which the spouse's share may be scanty, which may infringe on the rights of a housewife. The legal regime of spouses' property may be more beneficial to her. The civil registry office does not have the authority to examine the content of a prenuptial agreement, but can only verify its existence. The introduction of such a measure of responsibility as declaring a marriage void upon the marriage with a foreign citizen without the fact of a year of residence in the republic and the conclusion of a marriage contract will only give rise to the law circumvention and will not achieve the necessary preventive effect. If the thing is about marrying people who want to live in Tajikistan, then there is a possibility of a marriage in the republic and the compliance with these conditions.

Another possibility of a marriage involving foreigners and stateless persons are consular marriages.

The regulatory legal acts of Belarus, Ukraine, Kazakhstan, regulating family relations with the participation of foreigners, contain the rules on the possibility of marriage at consular posts or diplomatic missions, providing the so-called consular marriages.

The problem of "consular" marriages was touched upon in the writings of many civilists (Lehmann, 2020; Briggs, 1999; Stewart, 2009). However, there are enough problems in this area. As Hannum and Lillich, (1980) noted correctly, "each state claims that not only the law of this state be applied to all private individuals in its territory, but also that this right is also applied to the citizens of this state and outside its territory" (Hannum and Lillich, 1980). Registration of marriage in the relevant state or church institutions refers to local forms. However, there are situations when marriage is registered at the diplomatic or consular offices of the countries that sent an ambassador or a consul. This is a case of extraterritorial forms of marriage. In this case, the marriage is concluded on the territory of one state, but at a diplomatic mission or a consular office of another state.

The family legislation of the Russian Federation provides for a marriage on the conditions of reciprocity in consular posts and diplomatic missions of the Russian Federation, if both persons entering into marriage have Russian citizenship and live abroad.

The Code of the Republic of Belarus "On Marriage and Family" (1999) allows for the possibility of marriage not only between foreigners who have the citizenship of the country, which sent an ambassador or a consul, but also a marriage between a citizen of that country and a stateless person on condition of reciprocity. 
Gulshan Gurezovna Bodurova y Sanavbar Nazirkulovna Tagaeva

Tendencies for the Development of Marriage Conflict Legal Regulation with the Participation of 358

Foreigners and Persons without Citizenship in the Post-Soviet Space

The Law of Ukraine "On Private International Law" allows for the possibility of marriage between foreigners at a consular post or a diplomatic mission of the corresponding state in Ukraine according to the legislation of a foreign state (Part 2 of the Article 57). At the same time, the law does not stipulate the requirements for the presence of citizenship of both foreigners of the foreign state that sent an ambassador or a consul.

This circumstance testifies to the possibility of subsequent recognition of consular marriages committed in the territory of the consular state of residence between citizens of a third state from a legal point of view. Such a situation cannot be the basis for recognizing a marriage subsequently "lame" in one of the countries.

In turn, the Code of the Republic of Kazakhstan "On Marriage (Matrimony)" provides for the recognition of marriages concluded in diplomatic missions and consular offices of foreign states located in the country, if this marriage does not contradict the legislation of the Republic of Kazakhstan (Part 2 of the Article 229). It turns out that the legislation of the Republic of Kazakhstan considers the absence of a contradiction with the legislation of the country as the basis for the recognition of consular marriages.

In turn, there is the possibility of marriages between citizens of the Russian Federation living outside the country in diplomatic missions or consular posts.

As well as the possibility of marriage at a consular post or a diplomatic mission of Ukraine depends on the residence, at least one of the persons entering into the marriage outside Ukraine.

The Code of Kazakhstan "On Marriage (Matrimony)" allows for the possibility of marriage at one of the consular posts or diplomatic missions abroad not only between the citizens of the Republic of Kazakhstan, but also mixed marriages when one of the parties is a foreigner or a stateless person. In this situation, the possibility of lame marriages is not ruled out, since one of the persons entering into a marriage may be a foreigner holding the citizenship of the state where the consular post or the diplomatic mission is located.

\section{Summary}

Thus, the study of marriage conflict regulation trends involving foreign persons and stateless persons in the post-Soviet space plays an important role in their legal regulation both at the legislative level and in the framework of regional agreements. Moreover, marriage and family relations are 
increasingly integrated and go beyond the legal regulation of individual countries more intensively. On this issue Heila Sha (Saheira Haliel) notes that transnational marriages are mostly associated with migration, that is, as the author believes mixed marriages are the result of migration and trade relations. Brettell (2017) also emphasizes that migration is a major factor of cross-border marriage development (Brettell, 2017).

Conflict regulation of a marriage at a consular post or a diplomatic mission develops in two directions: a) regulation of legal norms so that they do not allow the possibility of "lame marriages"; b) ignoring the legal consequences of a marriage, providing freedom of marriage not only to their citizens, but also to foreigners (stateless persons), when they enter into a marriage with the citizens of the country.

\section{Conclusions}

Thus, two approaches have been formed for the regulation of consular marriages in the post-Soviet space: a) the approach aimed at prevention the occurrence of "lame marriages". In this case, states grant the right to marry at a diplomatic mission or a consular post only to their citizens, while not allowing the possibility of "mixed marriages" or allow them to be concluded if there is reciprocity; b) the approach that does not take into account the rule of law of the country in which the diplomatic mission or the consular post is located for mixed consular marriages, that is, providing the opportunity to marry not only between citizens of the country, but also between the citizens of the country and foreign citizens or between the citizens of the country and the persons without citizenship.

Based on the foregoing, we can conclude that two trends are observed with the conflict regulation of marriage in the country of the post-Soviet space: a) the possibility of marriage relation conflict regulation by the persons entering into marriage via legal consequence determination; b) increased state intervention in the conflict regulation of marriage.

\section{Acknowledgements}

The work is performed according to the Russian Government Program of Competitive Growth of Kazan Federal University. 
Gulshan Gurezovna Bodurova y Sanavbar Nazirkulovna Tagaeva

Tendencies for the Development of Marriage Conflict Legal Regulation with the Participation of

360

Foreigners and Persons without Citizenship in the Post-Soviet Space

\section{Bibliographic References}

BRETTELL, Caroline B. 2017. "Marriage and Migration" In: Annual Review of Anthropology. Vol. 46, No. 91, pp. 81-97.

BRIGGS, Adrian. 1999. "Private International Law" In: British Yearbook of International Law. Vol. 70, No. 1, pp. 319-347.

CLARKSON, C; HILL, J. 2006. The Conflict of Laws. Oxford: University Press. Oxford, United Kingdom.

DESSEMONTET, F; ANSAY, T. 2004. Introduction to Swiss Law. The Hague: Kluwer Law International. USA, New York.

HANNUM, Hurst; LILLICH, Richard. 1980. "The Concept of Autonomy in International Law" In: The American Journal of International Law. Vol. 74, No. 4, pp. 858-889.

LEHMANN, Mattthias. 2020. "Regulation, global governance and private international law: squaring the triangle" In: Journal of Private International Law. Vol. 16, No. 1, pp. 1-30.

LUNDSTEDT, Lydia; SINANDER, Erik. 2020. "Enhancing critical thinking in private international law" In: The Law Teacher. Vol. 54, No. 3, pp. 400413.

MATVEEV, G.K. 1972. "The issues of the Soviet conflict of family law" In: Jurisprudence. No. 2, pp. 99-105.

MENGLIEV, S. 2001. "The fundamental beginning in the regulation of international private law relations" In: Davlatvahukuk No. 2, pp. 74-78.

PANTELEEVA, I.Y. 1986. Marriage in Private International Law: Thesis by the $\mathrm{PhD}$ in Law. Moscow State University. Moscow, Russia.

SEN, Samita; BISWAS, Ranjita; DHAWAN, Nandita. 2011. "Intimate Other Marriage \& Sexualities in India" In: Sage Journals. Available online. In: https://doi.org/10.1177/2393861715574419. Consultation date: 14/11/2018.

SHA, Heila. 2020. "Transnational marriage in Yiwu, China: trade, settlement and mobility" In: Journal of Ethnic and Migration Studies. Vol. 46, No. 11, pp. 2326-2345.

STEWART, David P. 2009. "New Directions in Private International Law" In: Agenda International. Year XVI, No. 27, pp. 255-269. 

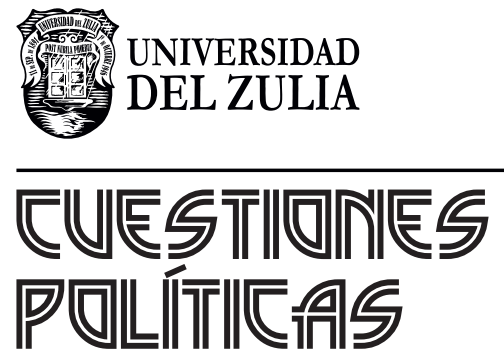

Vol.38 NEspecial

Esta revista fue editada en formato digital y publicada en diciembre de 2020, por el Fondo Editorial Serbiluz, Universidad del Zulia. Maracaibo-Venezuela 